Agro-Science Journal of Tropical Agriculture, Food, Environment and Extension Volume 18 Number 3 (September 2019) pp. 1-4

ISSN 1119-7455

\title{
EFFECTS OF PRUNING LOCATION ON GROWTH AND FRUITING OF THREE TOMATO (Lycopersicon esculentum Mill) VARIETIES IN RAINFOREST ZONE OF NIGERIA
}

\author{
"Falodun E.J. and Ogedegbe S.A. \\ Department of Crop Science, Faculty of Agriculture, University of Benin, Nigeria \\ *Corresponding author’s email: ehizogie.falodun@uniben.edu
}

\begin{abstract}
A field experiment was carried out during the 2016/2017 dry cropping season at the Experimental Farm of the Department of Crop Science, Faculty of Agriculture, University of Benin, Benin City to examine the effects of location of pruning on some vegetative and reproductive attributes of tomato varieties. The trial was laid out in a $3 \times 4$ factorial arrangement fitted in a randomized complete block design in three replicates with twelve treatment combinations per replicate and 36 for the whole replicates consisting of four location of pruning, P1 (pruning the tips only), P2 (pruning the lateral suckers only), P3 (pruning the tips and lateral suckers) and PO (control, i.e., no pruning) on three varieties of tomatoes V1 (Cobra), V2 (Roma VF) and V3 (UC82). The results showed that Cobra variety produced higher fruit weight/plant $(37.86 \mathrm{~g})$ and more number of rotted fruits (1.42) than other varieties. Roma VF showed superiority in number of branches /plant (22.58) compared with Cobra variety (15.42) and UC82 (14.67). Pruning at P1 and P0 increased number of branches (23.33 and 21.89) than P2 (14.56) and P3 (10.44) Number of leaves increased in P1 compared with P2 and P3 and the leaf area increased at P3 $\left(36.32 \mathrm{~cm}^{2}\right)$ more than PO $\left(28.34 \mathrm{~cm}^{2}\right)$. The rotted fruits increased in this order P2, P3 > P0, P1. Since pruning increased the number of rotted fruits/plant but produced non-significant increases in fruit weight/plant $(g)$ and fruit yield $\left(t h^{-1}\right)$, any of the three varieties of tomato could be used in Edo rain-forest zone of Nigeria at no pruning.
\end{abstract}

Key words: cultural practices, leaf area, rotted fruits, stem diameter, suckers

\section{INTRODUCTION}

Tomato (Lycopersicon esculentum) is the second most important vegetable crop next to potato. Yield of tomatoes in the tropics is generally low, in Africa average yield of 8-25 $\mathrm{Mt} \mathrm{ha}^{-1}$ was recorded, with the highest yield from South Africa and the least from Benin and Nigeria (De Lannoy, 2000). Shortage of varieties that are adaptable to different agro-ecologies makes the list of the major constraints to tomato production in Nigeria (Asgedom et al., 2011). Tomato yield could be increased substantially through improved agronomic techniques like the use of improved varieties of seeds and pruning. Olaniyi et al. (2010) reported that fruit yield per plant and total fruit yield differed among varieties due to genetic differences. Rafi (1996) and Chen and Lal (1999) recommended pruning as a cultural practice that improves the yield and quality of tomato. Pruning is a horticultural and silvicultural practice involving the selective removal of certain parts of plant to improve growth and yield of a plant. This practice helps to divert nutrients to flower clusters and fruits on the main stem and allows more efficient air circulation. Wuster and Nganga (1970) stressed that, properly supported and pruned plants that are appropriately spaced produce larger, earlier and relatively reasonable fruit yield than nonpruned and non-staked plants of the same variety. It is necessary to pinch off the growing tip or tips so that the remaining fruits have a chance to ripen (Tonya, 2006). Although pruning can be a tedious task, it is immensely satisfying to harvest a large crop of juicy, healthy tomatoes all season long. George (2004) revealed that pinched plants produced multiple terminal growths that bore flowers and hence, increased fruit formation and size. Inadequate application of improved cultural practices may be some of the factors that limit tomato production, hence, farmers in Nigeria obtained very low yield compared with global yield. Pruning and the use of improved varieties for planting could help to increase tomato fruit yield for a worthwhile economic returns. It is on the basis of the above that the present study was designed to determine the effects of pruning on the growth and fruit yield of three varieties of tomato in Edo rainforest zone of Nigeria. 


\section{MATERIALS AND METHODS}

The experiment was carried out in the dry season of 2016/2017 at the Teaching \& Research Farm of the University of Benin, Ugbowo Campus, Benin-City, in Edo State $\left(5^{0} 44^{\prime \prime} \mathrm{N}, 7^{0} 34^{\prime \prime}\right.$ and $\left.5^{\circ} 04^{\prime \prime} \mathrm{N}, 6^{0} 43^{\prime \prime} \mathrm{E}\right)$ on elevation of $162 \mathrm{~m}$ asl. The climate is tropical and the vegetation is rainforest in the south with mean annual rainfall of $2300 \mathrm{~mm}$ to guinea savanna in Edo North with 1400 mm mean rainfall. Meteorological data during the experimental period was obtained from Nigerian Institute for Oil Palm Research (NIFOR) and is presented in Table 1.

\section{Soil Sampling and Analysis}

Prior to planting soil samples were taken randomly from 10 points with a soil auger at a depth of 0-30 $\mathrm{cm}$, thoroughly mixed to form a composite sample, air-dried and crushed to pass through a $2 \mathrm{~mm}$ sieve. Soil $\mathrm{pH}$ was determined using a $\mathrm{pH}$ meter. Organic carbon was determined by Walkley-Black's wet oxidation method as modified by Jackson (1969). Total nitrogen was obtained by macro Kjeldahl methods as modified by Jackson (1969). Available P was extracted by Bray I method (Bray and Kurtz, 1945) and the $P$ was estimated by the blue colour method of Murphy and Riley (1962). Exchangeable $\mathrm{K}$ and $\mathrm{Na}$ were determined using flame photometer, while $\mathrm{Ca}$ and $\mathrm{Mg}$ were determined using the Atomic Absorption Spectrophotometer, after which effective cation exchange capacity (ECEC) was calculated as the sum of exchangeable bases and exchangeable acidity (Ibitoye, 2008).

\section{Treatments and Experimental Design}

The treatments were factorial combinations of four locations of pruning P0 (no pruning), P1 (pruning at the tips only), P2 (pruning at the lateral suckers only, P3 (pruning at the tips and the lateral suckers) and three varieties of tomato namely V1 (Cobra), V2 (Roma VF) and V3 (UC28) which are commonly bushy, mid to early maturing and are semi determinate types of tomato. The experiment was laid out as a randomized complete block design (RCBD) with three replications. Each replicate had 12 plots of a total of 36 plots in this experiment. The land for transplanting measuring $12 \mathrm{~m} \times 29.1 \mathrm{~m}$ was prepared manually with the residues incorporated into the soil. Beds measuring $1.8 \mathrm{~m} \times 3 \mathrm{~m}$ were prepared and tomato seeds were sown in the nursery on $14^{\text {th }}$ of October, 2016 and seedlings transplanted to the field on $5^{\text {th }}$ November , 2016 when seedlings were three weeks old at a spacing of $60 \mathrm{~cm} \times 90 \mathrm{~cm}$ giving a plant population of 360 plants/plot and 10,309.27 plants/ hectare.

\section{Cultural Practices}

Plots were mulched with dried grasses immediately after transplanting. Weeding was done manually at 3, 6 and 8 weeks after transplanting (WAT). Pruning was done during 3-8 WAT.
Table 1: Meteorological data at the University of Benin study site during the field study (Sep. 2016 - Apr 2017)

\begin{tabular}{lccc}
\hline Month & $\begin{array}{c}\text { Rainfall } \\
(\mathrm{mm})\end{array}$ & $\begin{array}{c}\text { Air } \\
\text { temperature }\left({ }^{0} \mathrm{C}\right)\end{array}$ & $\begin{array}{c}\text { Relative } \\
\text { humidity }(\%)\end{array}$ \\
\hline September & 175.0 & 26.2 & 86.75 \\
October & 157.7 & 31.0 & 85.25 \\
November & 58.8 & 28.3 & 78.35 \\
December & 31.1 & 28.4 & 69.05 \\
January & 0.00 & 28.7 & 51.30 \\
February & 7.0 & 28.6 & 72.35 \\
March & 155.1 & 27.9 & 74.25 \\
April & 84.6 & 28.3 & 77.40 \\
\hline
\end{tabular}

Statistics Division of Nigeria Institute for Oil Palm Research (NIFOR) Benin - City, Edo State, Nigeria

\section{Sampling and Measurements}

Data collection commences 4WAT. Four plants were randomly selected from each net plot measuring $(1.8 \mathrm{~m} \times 3 \mathrm{~m})$ and tagged for the purpose of collecting data. Plant height $(\mathrm{cm})$, was measured using a meter rule, the stem diameter using vernier caliper (Baker Grey SDN 10, (India), leaf area was estimated at 5WAT by substituting the leaf rectangular area (LRA) derived from leaf length and breadth into the fitted equations for leaf area (Bodunde and Olanrewaju, 2003):

$$
\mathrm{Y}=14.46+0.79 \mathrm{X}
$$

where $Y$ is leaf area and $X$ is product of the length and breadth of the leaf, while numbers of leaves, number of branches, number of flowers and number of fruits were visually assessed. Fruit weight was measured using an electric weighing balance (Furi spec, China), and the average was taken and recorded while individual treatment yields were computed on fresh weight basis as sum of all harvests from individual net plots $(\mathrm{kg})$ extrapolated to one hectare. Other parameters taken were fruit length and fruit diameter and these were done by measuring through the longitudinal section and transverse section of the fruits respectively using Vanier caliper (Baker Grey SDN 10, India).

\section{Statistical Analysis}

The data obtained were subjected to statistical Analysis of Variance (ANOVA) using Statistical Analysis System (SAS) version 1998, following the model for factorial experiment in an RECB and differences among treatments were separated using the Least Significant Difference (LSD) at $p \leq 0.05$.

\section{RESULTS}

\section{Soil Properties}

The physico-chemical properties of the soil of the study area show that the soil is sandy loam and acidic (Table 2). It had organic matter of $2.71 \%$. The total $\mathrm{N}$ was adequate $(0.83 \%)$ but with low amounts of available $\mathrm{P}\left(6.02 \mathrm{mg} \mathrm{kg} \mathrm{kg}^{-1}\right)$ and exchangeable bases when compared with the recommended critical levels of $0.15 \% \mathrm{~N}, 10-16$ $\mathrm{mg} / \mathrm{kg} \mathrm{P}$ and $0.34 \mathrm{cmol} / \mathrm{kg} \mathrm{K}$ for crop production (Aduayi et al., 2002). 
Table 2: Physico-chemical properties of the soil from the experimental site before planting

\begin{tabular}{ll}
\hline $\mathrm{pH} 1: 2.5$ water and soil & 4.65 \\
Phosphorus $\left(\mathrm{mg} \mathrm{kg}^{-1}\right)$ & 6.02 \\
Total Nitrogen $(\%)$ & 0.83 \\
Organic matter $(\%)$ & 2.71 \\
Exchangeable Calcium $\left(\mathrm{cmol} \mathrm{kg}^{-1}\right)$ & 0.78 \\
Exchangeable Magnesium $\left(\mathrm{cmol} \mathrm{kg}^{-1}\right)$ & 0.30 \\
Exchangeable Potassium $\left(\mathrm{cmol} \mathrm{kg}^{-1}\right)$ & 0.15 \\
Exchangeable Sodium $\left(\mathrm{cmol} \mathrm{kg}^{-1}\right)$ & 0.12 \\
Exchangeable Aluminium $\left(\mathrm{cmol} \mathrm{kg}^{-1}\right)$ & 0.16 \\
Exchangeable Hydrogen $\left(\mathrm{cmol} \mathrm{kg}^{-1}\right)$ & 0.53 \\
Effective Cation Exchange Capacity $\left(\mathrm{cmol} \mathrm{kg}^{-1}\right)$ & 1.51 \\
Sand $\left(\mathrm{g} \mathrm{kg}^{-1}\right)$ & 892.00 \\
Silt $\left(\mathrm{g} \mathrm{kg}^{-1}\right)$ & 53.00 \\
Clay $\left(\mathrm{g} \mathrm{kg}^{-1}\right)$ & 55.00 \\
Textural class & Sandy loam \\
\hline
\end{tabular}

Growth Response of Tomato (Lycopersicon esculentum Mill) Varieties to Location of Pruning There were significant varietal differences in some of the vegetative characters measured except for stem diameter (Table 3). Cobra significantly produced the tallest plants $(72.19 \mathrm{~cm})$ which were taller compared to Roma VF $(61.98 \mathrm{~cm})$, but not UC82 $(67.44 \mathrm{~cm})$. Number of leaves and branches were significantly higher in Roma VF than UC82; however, pruning at both the tips and suckers (P3) increased leaf area $\left(36.32 \mathrm{~cm}^{2}\right)$ above control, P0. Though location of pruning had no effect on plant height, the number of branches significantly increased in this order P0, P1 > P2, P3 compared to other locations of pruning P0 (21.89) and P1 (23.33), while the number of leaves increased in this order P0, P1 > P3 $\leq \mathrm{P} 2$ location. Pruning at P2 and $\mathrm{P} 3$ significantly $(\mathrm{p} \leq 0.05)$ produced the lowest number of branches (14.56 and 10.44), respectively.

Yield Attributes of Tomato (Lycopersicon esculentum mill) Varieties to Location of Pruning The number of fruits/plant was significantly higher in cobra variety (6.83) than UC82 (3.75) and this was comparable to the number of fruits per plant observed in Roma VF. The fruit length was higher in P1 than P2 however, this was comparable with P0 and P3 (Table 4). The fruits weight per plant $(37.86 \mathrm{~g})$ of Cobra variety was significantly higher than that produced by Roma VF (30.24 g) and UC82 (38.36 g/plant). The Cobra variety produced the highest number of rotted fruits per plant compared with other varieties, pruning at P2 (1.33) and P3 (1.39) were comparable and increased rotted fruits per plant than P0 (1.11) and P1 (1.00).

Table 3: Effects of location of pruning on some vegetative characters of three varieties of tomato

\begin{tabular}{|c|c|c|c|c|c|c|}
\hline \multirow[b]{2}{*}{ Treatment } & & \multirow[b]{2}{*}{ Plant height/plant $(\mathrm{cm})$} & \multirow[b]{2}{*}{ No of leaves/plant } & \multirow[b]{2}{*}{ No of branches/plant } & \multicolumn{2}{|c|}{ stem diameter } \\
\hline & & & & & $(\mathrm{cm}) /$ plant & Leaf area $\left(\mathrm{cm}^{2}\right)$ \\
\hline \multirow[t]{5}{*}{ Varieties } & Cobra & 72.19 & 99.33 & 15.42 & 1.45 & 33.65 \\
\hline & Roma VF & 61.98 & 121.42 & 22.58 & 1.63 & 34.53 \\
\hline & UC82 & 67.44 & 94.33 & 14.67 & 1.52 & 30.26 \\
\hline & LSD & 9.51 & 22.24 & 4.76 & 0.26 & 4.82 \\
\hline & & $*$ & $*$ & $*$ & ns & ns \\
\hline \multirow[t]{6}{*}{ Pruning } & $\mathrm{P} 0$ & 66.11 & 116.44 & 21.89 & 1.53 & 28.34 \\
\hline & $\mathrm{P} 1$ & 68.83 & 128.78 & 23.33 & 1.49 & 33.48 \\
\hline & $\mathrm{P} 2$ & 70.26 & 94.11 & 14.56 & 1.59 & 33.13 \\
\hline & P3 & 63.60 & 80.78 & 10.44 & 1.51 & 36.32 \\
\hline & LSD & 10.98 & 25.68 & 5.50 & 0.30 & 5.56 \\
\hline & & ns & $*$ & $*$ & ns & $*$ \\
\hline $\mathrm{V} \times \mathrm{P}$ & & ns & ns & ns & ns & ns \\
\hline
\end{tabular}

$\mathrm{P} 0=$ control, $\mathrm{P} 1=$ pruning the tips only, $\mathrm{P} 2=$ pruning the suckers only, $\mathrm{P} 3=$ pruning the tips and suckers;

$\mathrm{ns}=$ not significant, $*=$ significant at $5 \%$ level of probability, $\mathrm{V} \times \mathrm{P}=$ interaction

Table 4: Effects of location of pruning on some selected yield attributes of three varieties of tomato

\begin{tabular}{|c|c|c|c|c|}
\hline Treatments & $\begin{array}{l}\text { No. of } \\
\text { flowers/ } \\
\text { plot }\end{array}$ & $\begin{array}{c}\text { No. of } \\
\text { fruits/ } \\
\text { plant }\end{array}$ & $\begin{array}{c}\text { Fruit } \\
\text { diameter } \\
(\mathrm{cm})\end{array}$ & $\begin{array}{c}\text { Fruit } \\
\text { length } \\
(\mathrm{cm})\end{array}$ \\
\hline \multicolumn{5}{|l|}{ Varieties } \\
\hline Cobra & 42.58 & 6.83 & 6.03 & 6.12 \\
\hline Roma VF & 41.00 & 4.63 & 5.79 & 6.37 \\
\hline UC82 & 32.54 & 3.75 & 5.70 & 6.03 \\
\hline LSD & 18.09 & 2.81 & 0.43 & 0.47 \\
\hline Significance & Ns & $*$ & Ns & Ns \\
\hline \multicolumn{5}{|l|}{ Pruning } \\
\hline P0 & 40.67 & 6.33 & 5.97 & 6.28 \\
\hline P1 & 44.32 & 6.44 & 5.86 & 6.51 \\
\hline $\mathrm{P} 2$ & 30.44 & 3.83 & 5.81 & 5.77 \\
\hline P3 & 26.11 & 3.67 & 5.76 & 6.14 \\
\hline LSD & 20.89 & 3.25 & 0.50 & 0.54 \\
\hline Significance & ns & ns & ns & $*$ \\
\hline $\mathrm{V} \times \mathrm{P}$ & $\mathrm{ns}$ & ns & ns & ns \\
\hline
\end{tabular}

Table 5 : Effects of location of pruning on some selected yield attributes of three varieties of tomato

\begin{tabular}{|c|c|c|c|}
\hline Treatments & $\begin{array}{l}\text { No of rotted } \\
\text { fruits/plant }\end{array}$ & $\begin{array}{c}\text { Fruit } \\
\text { weight/plant (g) }\end{array}$ & $\begin{array}{c}\text { Fruit yield } \\
\left(\mathrm{kg} \mathrm{ha}^{-1}\right)\end{array}$ \\
\hline \multicolumn{4}{|l|}{ Varieties } \\
\hline Cobra & 1.42 & 37.86 & 473.42 \\
\hline Roma VF & 1.08 & 30.24 & 442.10 \\
\hline UC82 & 1.13 & 38.36 & 419.64 \\
\hline LSD & $\begin{array}{c}0.29 \\
*\end{array}$ & $\begin{array}{c}7.35 \\
*\end{array}$ & $\begin{array}{c}113.30 \\
\text { Ns }\end{array}$ \\
\hline \multicolumn{4}{|l|}{ Pruning } \\
\hline P0 & 1.11 & 31.96 & 437.10 \\
\hline P1 & 1.00 & 31.07 & 491.34 \\
\hline $\mathrm{P} 2$ & 1.33 & 27.89 & 430.80 \\
\hline P3 & 1.39 & 27.80 & 420.26 \\
\hline LSD & 0.13 & 8.49 & 128.51 \\
\hline Significance & $*$ & ns & $\mathrm{ns}$ \\
\hline $\mathrm{V} \times \mathrm{P}$ & ns & ns & ns \\
\hline
\end{tabular}




\section{DISCUSSION}

Differences in the varieties for the plant height, number of leaves and branches could probably be influenced by the genetic characteristics of these tomato varieties as reported by Bitala (2001). The reduction in number of branches and leaves with P2 and P3 when compared with P0 and P1 could be due to the earlier removal of suckers and tips from $\mathrm{P} 2$ and P3 and this supports the finding of Preece and Read (2005) who stated that pruning reduces some vegetative growth of tomato plants. The increase in leaf area with P3 when compared with $\mathrm{P} 0$ was probably due to the reduction in the number of leaves in P3. This was occasioned by pruning at the tips and suckers hence an increase in the net assimilation rate; attributable to compensatory assimilate production by the fewer leaves. The remaining P3 leaves expanded in size and consequently in assimilate production similar to the observation of Sahu et al. (2018). Furthermore, pruning directly stimulates the formation of enlarged leaves, increases mesophyll size and moisture content as well as lengthens the period of stomata opening (Sahu et al., 2018). Cobra variety produced the highest fruit weight per plant; however, pruning location did not influence the fruit weight per plant. These observations support the findings of Bielinski (2008) who reported a nonsignificant effect of pruning on the reproductive attributes of tomato plants studied. This situation suggests that the short compact varieties or cultivars might not require pruning or minimal pruning (Olson et al., 2006), whereas the opposite might be necessary for vigorous and tall cultivars.

The increase in number of rotted fruits with pruned plants and the reduction in the number of leaves and branches per plants especially at P2 and P3 may have contributed to the non significant effect of pruning on fruit yield. These results agree with Bielinski (2008) but disagree with Tswanya et al. (2012) who reported increases in fruit yield of pruned plants over plants that were not pruned.

\section{CONCLUSION}

The tomato variety Roma VF produced more number of branches per plant, however Cobra variety was found to be superior to Roma VF and UC82 tomato varieties in terms of fruit weight per plant. Pruning locations increased leaf area and number of rotted fruits in the tomato varieties.

\section{REFERENCES}

Aduayi E.A., Chude V.O., Adebusuyi B.A. and Olayiwola S.O. (2002). Fertilizer use and management practices for crops in Nigeria. Federal Ministry of Agriculture and Rural Development Abuja, Nigeria, pp. 63-65.

Asgedom S., Struik P.C, Heuvelink E. and Araia W. (2011). Opportunities and constraints of tomato production in Eritrea. African Journal of Agricultural Research, 6 (4), 956-967
Bielinski M.S. (2008) Early pruning effects on Florida 47 and Sungard tomato. Hortechnology, 18 (3), 467 - 469

Bitala M.F. (2001). The effect of pruning on growth and yield of tomato. Special Project Report. SUA, Morogoro. Tanzania. $46 \mathrm{pp}$.

Bodunde J.G. and Olarewayu J.D. (2003). Accuracy of leaf rectangular area adoption in growth studies: The case of tomato (Lycopersicon esculentum Mill): ASSET Series A 3 (3), 57-62

Bray R.H. and Kurtz L.T. (1945). Determination of total organic and available forms of $\mathrm{P}$ in soils. Soil Science, 59, 39-45

Chen J.T. and G. Lal (1999). Prunning and staking tomatoes. International Cooperator's Guide, AVRDC, UK., pp. 490

De lannoy G . (2000). Vegetables Crop Production in Tropical Africa. In: Raemaekers R.B. (ed). pp. 403459

George A. (2004). Horticulture Principles and Practices. Asoke K. (ed.) pp. 709-710.

Ibitoye A.A. (2008). Laboratory manual on basic soil analysis. Foladave Nig., Ltd, pp. 37-38

Jackson M.L. (1969). Soil Chemical Analysis. Constable and Co Ltd, London, U.K. 132 pp.

Murphy J. and Riley J.P. (1962). Modified single solution methods for determination of phosphorus in natural water. Analytical Chemistry Acta, 27, 31-36

Olaniyi J.O., Akanbi W.B., Adejumo T.A. and Akande O.G. (2010). Growth, fruit yield and nutritional quality of tomato varieties. African Journal of Food Science, 4 (6), 398-402

Olson S.M, Stall W.M, Momol M.T., et al. (2006). In vegetable production hand book for Florida (University of Florida, Institute of food and Agricultural Sciences and Vance publishing, Lincolnshire, IL), Pp 467-426

Preece JE Read PE (2005). The Biology of Horticulture. 2nd ed. Copyright by John Wiley and Sons. New York, United States, $528 \mathrm{pp}$.

Rafi U.M. (1996). Stem pruning and spacing and spacing effect on the yield of tomato. ARC-AVRDC Training Report. Kasetsart University, Bangkok, Thailand: ARC-AVRDC, pp: 168-173

Sahu C.K., Patel M.K. and Panda C.M. (2018). Effect of pruning and plant growth regulator on plant growth and fruit yield of sapota (Manilkara zapota L.) cv. Cricket Ball. International Journal of Current Microbiology and Applied Science, 7 (9), 1352-1357

Statistical Analysis System (SAS) (1998). SAS Users Guide Com. NC. Statistical Analysis Institute, pp 256

Tonya S. (2006). Practicing home and garden. How to prune tomatoes / How to do things. http://www.how todothings.com/home-and-garden (accessed February 9, 2007)

Tswanya M.N., Oladiran J.A., Isah K.M., Lile S.N. and Yisa P.Z. (2012). Effect of staking and pruning on growth and seed yield of four tomato varieties (Lycopersicon esculentum Mill) in the Southern Guinea Savanna of Nigeria. International Journal of Agricultural and Development Economics, 2, 112-124

Wuster R.T. and Nganga S. (1971). The effect of staking and pruning on the yield and quality of fresh market tomatoes in East Africa. Acta Horticulturae (ISHS), 21, $110-115$ 